\title{
Public Professionals' Engagement in Coproduction: The Impact of the Work Environment on Elderly Care Managers' Perceptions on Collaboration With Client Councils
}

\author{
Carola van Eijk' (D), Trui Steen ${ }^{2}$, and René Torenvlied ${ }^{3}$
}

\begin{abstract}
In the context of public service delivery, public professionals nowadays intensively collaborate with citizens. The joint, sometimes mandatorily, efforts of citizens and professionals to provide public services have become known as "coproduction." Although coproduction directly affects professionals' work environment, professionals' attitudes toward coproduction are hardly studied. This article explains variation in professionals' engagement in coproduction from characteristics of their work environment, specifically their perceived level of autonomy, perceived organizational support for coproduction, and perceived red tape associated with coproduction activities. Survey research was conducted to question managers of Dutch organizations for elderly care about their interaction with client councils, an example of coproduction activities in the domain of health care. The results show that perceived autonomy in coproduction, red tape associated with coproduction, and organizational support affect professionals' engagement. Organizational support moreover reinforces the effect of work autonomy on professionals' perception on the importance of coproduction. These findings add to the study of coproduction and can help support public organizations to improve coproduction.
\end{abstract}

\section{Keywords}

coproduction of public services, autonomy, organizational support, red tape, client councils in organizations for elderly care

\section{Introduction}

For decades, public administration has struggled with the question of how to bring the general public into administrative processes. Involvement of the public in administrative processes concerns not only citizens' rights and responsibilities but also how public professionals "view themselves and their responsibilities relative to citizens" (Thomas, 1999, p. 83). Public professionals operate in constantly changing environments, directly affecting their role perceptions vis-àvis citizens (cf. Osborne, 2010).

In many administrative systems, coproduction is introduced, sometimes mandatorily, to involve the public in public service delivery (Osborne, Radnor, \& Nasi, 2012; Osborne $\&$ Strokosch, 2013). The development of coproduction is, among other things, induced by austerity measures in public finances and associated with a legitimacy crisis in public sector and private market performance. Coproduction can be defined as a process in which citizens co-plan, co-design, coprioritize, co-finance, co-deliver, and/or co-assess public services alongside their "traditional" producers (i.e., public professionals) - with the aim of enhancing the quality of public services delivered and produced (Bovaird \& Löffler, 2012; Brandsen \& Honingh, 2016; Brandsen, Pestoff, \& Verschuere, 2012).

The introduction of coproduction in the activities of public professionals directly affects their work environment. Coproduction requires public professionals to share their power, tasks, and responsibilities with citizen-users. Thus, coproducers and public professionals become collaborators in an effort to secure continuity and quality in the delivery of public services (Brandsen et al., 2012; Ewert \& Evers, 2012).

Like other kinds of collaboration, coproduction implies that public professionals' perception of coproduction impacts on the effectiveness of coproduction. Walter (1987), for example, shows how public managers create meaning, and

\footnotetext{
'Leiden University, The Hague, The Netherlands

${ }^{2} \mathrm{KU}$ Leuven, Belgium

${ }^{3}$ University of Twente, Enschede, The Netherlands

Corresponding Author:

Carola van Eijk, Institute of Public Administration, Leiden University, Attn. C. Van Eijk, P.O. Box I3228, 250 I EE The Hague, The Netherlands. Email: c.j.a.van.eijk@fgga.leidenuniv.nl
} 
clarify roles, to stimulate volunteering by citizens. Lemos and Morehouse (2005) argue that demonstrated openness to incorporate stakeholders is crucial for establishing trust and credibility in coproduction.

Despite a long-standing coproduction research tradition (cf. Calabrò, 2012; Verschuere, Brandsen, \& Pestoff, 2012), the attitudes of public professionals toward coproduction are hardly studied. Indeed, Fenwick (2012) concludes that empirical studies "at the front lines of everyday practice" are rare. This article fills this gap by studying public professionals' self-reported engagement in coproduction. Engagement in coproduction comprises three dimensions: perceived importance of coproduction, perceived impact of coproduction, and personal involvement in coproduction. This article seeks to explain variation in public officials' engagement from characteristics of their work environment, more in particular their perceived level of autonomy, perceived organizational support for coproduction, and perceived red tape associated with coproduction activities.

Empirically, we study variation in public officials' engagement in coproduction in the context of client councils in Dutch elderly care. As collaboration with these client councils is enforced by law, this case provides the unique opportunity to investigate whether and why professionals share similar viewpoints on this collaboration. Client councils in Dutch elderly organizations collaborate with the location manager on issues of organizational (strategic) management and quality of the health care provided to the elderly clients. So, our case is about co-planning as a specific form of coproduction. Thus, the research question is as follows:

Research Question: How do location managers' perceptions of their autonomy, organizational support, and red tape explain their engagement in coproduction with client councils in Dutch organizations for elderly care?

The next section presents theoretical insights that link public professionals' autonomy and perceptions of organizational support for and of red tape in coproduction to their engagement in coproduction. For each of these explanations we derive hypotheses. Subsequently, we describe the empirical context of Dutch client councils followed by a section on study design and research methods. Results of the analyses are presented and implications for research and practice are discussed.

\section{Engagement in Coproduction}

Coproductive public service delivery involves citizens (the coproducers) and public service professionals as "traditional" producers of public services (Brandsen et al., 2012, p. 1). In line with coproduction literature, the term "public service professional" is used here in a colloquial sense of the word - referring to a person who works for a public or quasipublic organization and is responsible for activities in the public service delivery process (Brandsen \& Honingh, 2016; Ostrom, 1996). This broad definition should not be confused with strict definitions used in, for example, literature on professionalism (cf. Freidson, 1994, 2001). Although in literature on professionalism the features on jobs that can be labeled as "professional" are rather strict, in coproduction literature, for example, also the managers responsible for collaboration with citizens are labeled professional.

Although many scholars perceive coproduction as highly valuable (cf. Calabrò, 2012), as such it does not occur spontaneously. To secure benefits from coproduction, an essential precondition is that both citizens and public service professionals are truly engaged in coproduction (Loeffler \& HineHughes, 2013; Ostrom, 1996). The mutual engagement of citizens and public service professionals can - in part-be stimulated by (selective) incentives (e.g., the establishment of contracts) and emerges when credible commitment and trust between coproduction partners is built (Ostrom, 1996).

Engagement in coproduction has been, and almost exclusively, studied from the perspective of citizens. Thomsen (2017), for example, shows that the effort citizens put into coproduction highly varies with individual characteristics (i.e., their knowledge of how to coproduce and their selfefficacy). The imperative of collaboration in coproduction requires that public service professionals are also engaged in coproduction: willing to listen to the ideas and concerns of clients and actively sharing information. An attitude toward collaboration encourages citizens to keep motivated (Van Eijk \& Steen, 2016). "Managers who are personally involved with users' activities, who are being helpful and whose leadership style is less hierarchical, are more likely able to create a feeling of reciprocity among the group of participants" (Fledderus, 2015, p. 561).

Thus, it is important professionals are not just involved in coproduction but feel really engaged with the collaboration with citizens. Involvement means that a professional takes part in the collaboration (e.g., as the result of a legal obligation). Engagement, moreover, implies that a professional is also willing to actively partake in the coproduction effortconvinced that collaboration is important, persuaded by its usefulness and functionality, and committed to collaboration. Hence, even when professionals have little discretion in the process of coproduction, their attitude remains highly important for its success.

\section{Characteristics of Professionals' Work Environment}

If then professionals' attitudes toward coproduction are crucial, it is important to gain insight into what explains differences in their willingness to engage in coproduction activities with clients. Reviewing research insights on the roles of the professionals in coproduction, Steen and Tuurnas (2018) conclude that a supporting organizational culture has an essential role for institutionalizing coproduction and encouraging professionals to 
include citizens in the service process. We study three characteristics of professionals' work environment as antecedents of their engagement: (a) their work autonomy in general and related to coproduction, (b) their perceived organizational support, and (c) red tape in general and associated with coproduction.

\section{Work Autonomy}

The "reward" of the status as a professional is, among other things, the autonomy to carry out the professional work (Bucher \& Stelling, 1969, p. 4; Flynn, 1999). Lipsky $(1980 / 2010)$ argues that street-level bureaucrats need discretion and autonomy to be flexible when carrying out dailywork activities. Coproduction activities are not exclusively performed by street-level bureaucrats (such as police officers, social workers, or health workers) but may also be performed by public managers. In performing their coproduction activities, public managers are not dissimilar from classical street-level bureaucrats, defined by Lipsky (1980/2010) as "[p]ublic service workers who interact directly with citizens in the course of their jobs, and who have substantial discretion in the execution of their work" (p. 3).

Some scholars argue that professional (work) autonomy is a crucial condition for professionals to perform well (Tummers \& Bekkers, 2014). Indeed, the literature on work engagement suggests that vitality, enthusiasm, and devotion are positively affected by perceived work autonomy (Saks, 2006). In turn, more engaged employees are found to better perform, be more creative, and show a willingness to carry out additional tasks (Bakker \& Demerouti, 2008). As coproduction activities imply innovative ways of delivering services and require additional tasks, we expect that higher levels of perceived work autonomy positively affect professionals' engagement in coproduction activities. Thus, our first hypothesis states that

Hypothesis 1 (H1): Professionals' perceived work autonomy positively affects their engagement in coproduction.

However, there is a special twist when it comes to coproduction. For our argument, it is important to emphasize that we are interested in co-planning as a specific form of coproduction. In this kind of coproduction processes, coproducers' involvement decreases professionals' freedom to make individual decisions and, hence, reduces the autonomous role and position of the professional in relation to clients. In the first place, mandatory coproduction (enforced by law, as in the case under scrutiny) limits professionals' options to autonomously decide upon the own work methods. In the second place, coproduction affects professionals' autonomous position vis-à-vis clients. Brandsen and Honingh (2013) and Moynihan and Thomas (2013) suggest that citizen involvement affects professionals' (level of) expertise, legitimacy, and autonomy. Whereas professionals traditionally were exclusive producer of public services (planning, designing, and implementing public services), more actors become involved in coproduction: service users, families, volunteers, neighbors, and other people become partners in the planning, designing, prioritizing, financing, and/or delivery stages (Bovaird \& Löffler, 2012). Entering the professionals' domain with a legitimate voice, citizens and professionals become more interdependent (Bovaird, 2007; Bovaird, Löffler, \& Hine-Hughes, 2011).

Rather than substituting professionals, citizens are complementary to them (cf. Pestoff, 2012). The professionalclient relation changes from a top-down, one-directional relationship (building users' trust in professionals and enforcing compliance), to a collaborative relationship based on user empowerment and interdependence (Ewert \& Evers, 2012). Coproduction obliges the professional to share power, tasks, and responsibilities with the "lay" citizen-user (Sharp, 1980, p. 105). It is professionals' new task to stimulate and motivate potential coproducers to pick-up responsibilities within service delivery (Alford \& O'Flynn, 2012). For professionally involved public servants, this shift implies a loss of managerial control.

On the contrary, and paradoxically, with blurring boundaries between professional and laymen responsibilities also comes a reduction in public accountability of professionals (Tonkens, Hoijtink, \& Gulikers, 2013). Again, this is most prominent in coproduction processes were citizens "intervene" in professionals' work environment, and so (potentially) undermine professionals' autonomy - such as in the co-planning activities investigated in this study. We argue that the more salient this dilemma of a reduction in autonomy in coproduction, the less engaged professionals will become. Hence, we formulated the second hypothesis as follows:

Hypothesis 2 (H2): Professionals' perceived autonomy in coproduction positively affects their engagement in coproduction.

\section{Organizational Support}

Alford and O'Flynn (2012) argue that for professionals to successfully adapt to their new roles in coproduction, organizational systems, structure, and culture need to change. Yet, what this change should contain remains unclear. Some studies provide more insight in specific factors that are stimulating or hindering citizen participation or coproduction. Huang and Feeney (2016) report that for public managers who are highly motivated by public values, a consistency between their values and organizational values and culture positively affects their willingness to engage the public in activities. Hence, in organizations with a culture supportive of coproduction, public professionals will be more convinced of the importance and usefulness of collaboration with clientsthus stimulating their engagement in coproduction.

Also organizational procedures, structures, and directives may be more or less supportive of coproduction and affect professionals' attitude (Evans, 2013). Huang and Feeney 
(2016), for example, report a negative effect between performance measurement and public managers' attitudes toward civic engagement. Voorberg, Tummers, et al. (2015) report how local civil servants' commitment with social innovation projects is challenged by the city administrative structures. In addition, professionals need resources to perform coproduction activities well, such as time and resources to organize and attend meetings. Coproducing clients often must be offered specific training programs. This results in the following hypothesis:

Hypothesis 3a (H3a): Professionals' perception of organizational support for coproduction positively affects their engagement in coproduction.

Hence, organizational support will not only directly impact on professionals' engagement in coproduction but also reinforce the positive effect of work autonomy on engagement. In political participation, we know that ineffective organization of the participation process, limited resourcing and timing, and a loose connection with policy processes hinder the integration of citizens' views, not only because citizens have difficulty to bring in their ideas and to get heard but also because civil servants are not stimulated enough to adapt to their new role (Lees-Marshment, 2015). Likewise, we argue that organizational support for coproduction provides professionals with a solid resource and cultural and organizational backup when interacting with clients/citizens in autonomy. The support offered by the organization stimulates professionals' belief that they are trusted by the organization to go outside, to develop new modes of interaction with the outside world, and are allowed to make decisions with and based on citizens' views (Spiegel, 1987; Van Eijk, 2018). Consequently, organizational support will positively impact on professionals' engagement in coproduction by enforcing their feeling of work autonomy. As such, we expect an interaction effect to exist between organizational support and work autonomy. This results in the following hypothesis:

Hypothesis 3b (H3b): Professionals' perception of organizational support reinforces the positive effect of autonomy on engagement in coproduction.

\section{Red Tape}

Formal structures and procedures may motivate professionals to engage in coproduction activities. However, such structures and procedures may also be perceived as administrative costs and burden, especially when commensurate benefits are absent (Brewer \& Walker, 2010). Burdensome rules can originate both inside and outside the organization, for example, due to external control or governmental structures and procedures (Bozeman, 2000). Perceptions on administrative burden, also referred to as "(perceived) red tape," vary between individual employees (Pandey \& Scott,
2002; Rainey, Pandey, \& Bozeman, 1995), negatively affecting, among other things, organizational performance (cf. Bozeman, 2000; Gore, 1993; Kaufman, 1977; Van den Bekerom, Torenvlied, \& Akkerman, 2017) and procedural satisfaction (Kaufmann \& Tummers, 2017).

Red tape can also originate as the result of interaction with stakeholders (Bozeman, 2000; Torenvlied \& Akkerman, 2012). Red tape can even be used by these stakeholders as a managerial or political tool to further their interests: By deliberately creating specific rules, red tape can advance a stakeholder's own agenda (Kaufmann \& Tummers, 2017). Here, of course, reference is made to more powerful stakeholder groups. Yet, also the interaction with less powerful groups - or stakeholders that cannot create rules themselves - can result in an increase of red tape. That is, managers might perceive or face the interaction as a burdensome increase in complexity. Red tape, as such, is a "socially constructed reality" (Pandey \& Marlowe, 2015) that impacts on individual's viewpoints and beliefs. In other words, the extent to which individuals face red tape impacts their stance toward the stakeholder interaction.

Interesting in this context is the interaction with or involvement of clients and citizens, as this closely relates to coproduction activities. Floring and Dixon (2004), for instance, argue that managers of health care services are skeptical about new public involvement arrangements due to the expected complexity and increase of red tape. Similarly, Huang and Feeney (2016) argue that the discouraging effect of performance measurement systems on public managers' motivation to invest time and resources in citizen participation may be further increased if participation is found to come with administrative burden, to be time-consuming, or difficult to coordinate. This finding is in line with Moynihan (2003) and Yang and Callahan (2007) who argue that expected administrative costs drive public managers' negative attitude toward civic engagement. When managers are confronted with "excessive rules and regulations," they will be less likely to recognize the added value of citizen participation and instead will emphasize the inefficiency and administrative delay it might bring to decision-making processes (Liao \& Schachter, 2018, p. 1300). This results in our fourth hypothesis:

Hypothesis 4 (H4): Professionals perceived levels of red tape associated with coproduction negatively affect their engagement in coproduction.

Yet, above we specified that red tape can also originate from other sources and activities than stakeholder activities. Davis and Pink-Harper (2016) find that individuals only partly judge the actual content of rules; the organization's social context and "second-hand information on the rule-breaking behavior of others" provide a much better explanation for how red tape perceptions develop. Red tape originating from different sources is found to also negatively impact on 


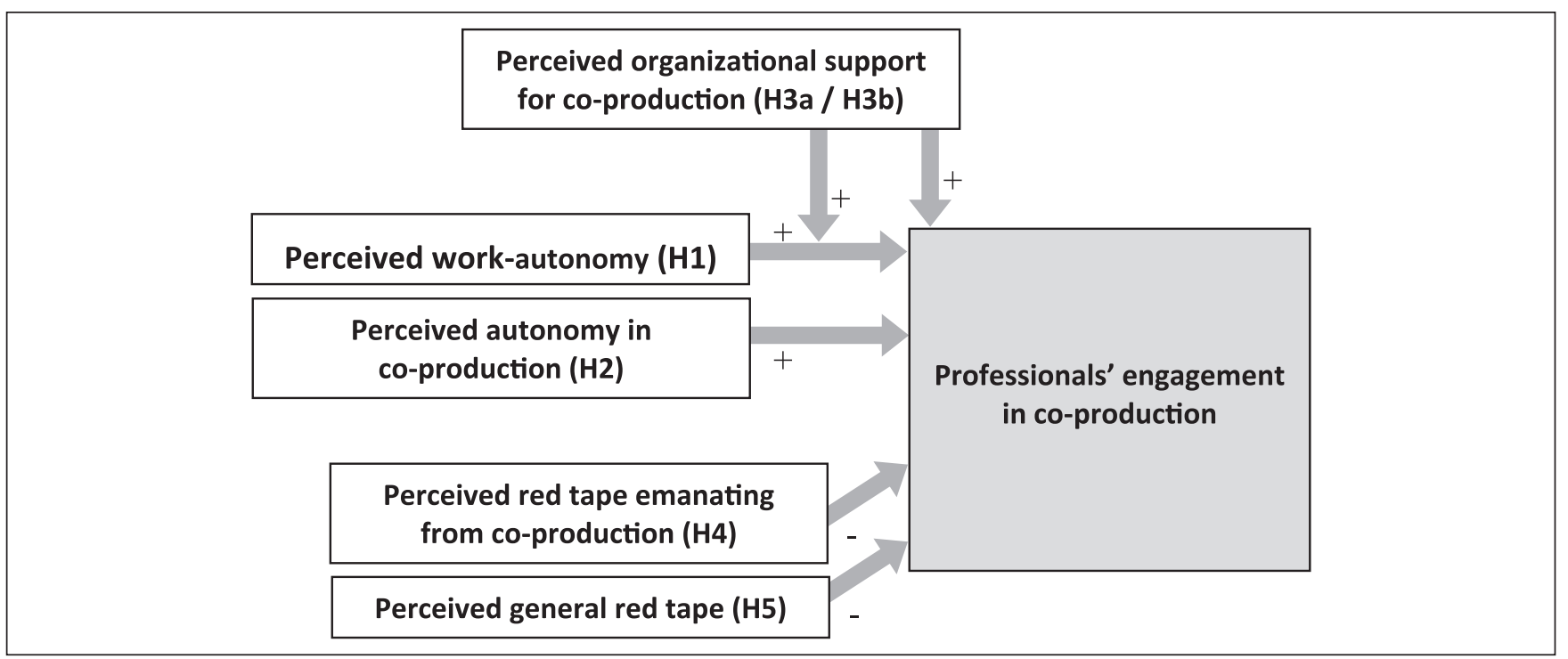

Figure I. Theoretical model explaining professionals' engagement in coproduction.

professionals' attitudes and performance. Red tape is, for example, negatively linked with public sector innovation and risk taking (Brewer \& Walker, 2010); an interesting finding in the context of this study as coproduction is often considered as a particular kind of social innovation (Voorberg, Bekkers, \& Tummers, 2015). Based on the specific sources and activities that result in perceived administrative burden, red tape research refers to different dimensions, including, for example, personnel red tape, budgetary red tape, procurement red tape, information red tape, and communication red tape as originally identified by Pandey, Coursey, and Moynihan (2007). Literature indicates different effects stemming from such different dimensions of red tape (Van Dijck \& Steen, 2017). Yet, it provides little insight in how precisely each of these different dimensions might affect engagement in coproduction. As we cannot only rely on professionals' perceptions on red tape originating in the coproduction context specifically, we add another hypothesis to study the impact of general red tape (including different potential sources) as opposed to this. So, we formulated a fifth and final hypothesis, namely,

Hypothesis 5 (H5): Professionals perceived levels of general red tape negatively affect their engagement in coproduction.

To wrap up, Figure 1 presents a stylized model with the hypotheses presented above.

\section{Client Councils in Organizations for Elderly Care}

The empirical context of this study is formed by the collaboration between location managers in organizations for elderly care with the client councils in their organization.
The Netherlands has a long tradition of patient' involvement. Within the last decades, patients have become actively involved as "partners" of the professionals (Van de Bovenkamp, 2010, p. 81). An important development in this respect is the institution of "client councils" in 1996. By Dutch law, all health care organizations are obliged to install a client council (Overheid.nl, 2012). For the present study, this nonvoluntary element is important from a methodological point of view, as it prevents biases that would occur if councils were exclusively formed on a voluntary basis.

Members of client councils are very diverse in their background, varying from direct patients (residents) to family members and even neighbors of the organization (Van Eijk \& Steen, 2014). The councils, thus, are a form of coplanning by service users: the council as a coproducer does not directly produce health care, but supports the organization's service delivery process indirectly (cf. Brandsen \& Honingh, 2016).

Client councils aim to enhance the quality of care provided. Dutch law has established a right of information for the councils. The councils provide input for management through a formal right (and initiative) of advice, at the strategic level as well as regarding the provision of care at the work floor. On some issues, the client council has a right of consent with management decisions. All these formal rights give client councils a uniform, horizontal position in coproduction. Despite its legal position, the de facto impact of a client council in coproduction with management is very much dependent on the perception of the location manager on coproduction. This informs the motivation for the present study.

In our survey (see the "Method" section), the managers provided input on how they involve the client council in the organizations' management. The examples show that sometimes managers and client councils only interact at a limited 
Table I. Composition of the Three Scales of Engagement With Coproduction $(N=342)$.

\begin{tabular}{ll}
\hline Subscale $^{\mathrm{a}}$ & Item \\
\hline $\begin{array}{l}\text { Importance } \\
\text { Organizational }\end{array}$ & "Involvement of users of our services is important within my organization." \\
$\begin{array}{l}\text { Democratic } \\
\text { Perceived impact }\end{array}$ & "Cooperation with clients is important from a democratic viewpoint." \\
Councils are influential & "Most times, the organization would have made the same decision." (reversed) \\
Councils have effect & "Cooperation with client councils increases the quality of service delivery." \\
Councils are efficient & "Cooperation with client councils demands more effort than worthwhile." (reversed) \\
$\begin{array}{l}\text { Personal involvement } \\
\text { Stimulate participation }\end{array}$ & "I involve members of the client council, even when it is not expected of me." \\
Satisfactory collaboration & "Professionally, I am satisfied with the collaboration with council members." \\
\hline
\end{tabular}

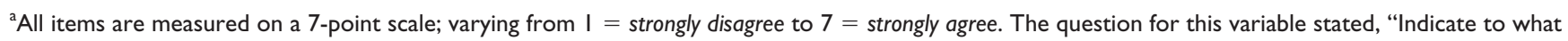
extent you agree or disagree with the following seven statements. We are interested in your opinion; answers cannot be good or bad."

number of fixed meetings. The manager attends the client council's meetings and listens to its ideas. In other cases, manager's and council's interaction is more frequent, not limited to formal meetings, and based on openness and transparency. For one of the respondents, the council acts "as a sounding board." Another lists, "I take a vulnerable attitude and together we try to critically judge our management processes." These differences between managers' perceptions on coproduction are also observed by members of the client council (Van Eijk \& Steen, 2014).

\section{Method}

To tap perceptions of location managers regarding coproduction with client councils, a survey was sent to all location managers of organizations for elderly care. All types of health care organizations for the elderly were included in the sample, which mainly vary in the intensity of care. Most nursing homes and centers for elderly care in the Netherlands are members of their sector confederation ActiZ, which is a sector-level partner for politicians and insurance companies (ActiZ, 2014). Approximately $70 \%{ }^{1}$ of all organizations for elderly care are member of ActiZ. All contact details of the relevant organizations for elderly care were made available to the researchers, which was subsequently validated and complemented with information from an authoritative list of organizations for elderly care published by the Dutch Health Care Inspectorate (Inspectie voor de Gezondheidszorg). For the population, we identified all "locations" of larger-scale nursing homes and centers for elderly care as individual units of analysis. This resulted in 1,970 potential respondents (i.e., location managers) nested in 372 coordinating nursing homes and centers for elderly care.

In 2014, the potential respondents were invited by e-mail to participate in an online survey. Two reminders were sent. After 10 weeks, the response rate was $22 \%(N=430)$. This response rate is understandable given the work pressure on location managers, the sweeping reforms they are confronted with, and the prevalence of survey research in the sector. Also note that locations had been merged or that location managers collaborated with multiple client councils. ${ }^{2}$ A nonresponse analysis (see appendix) shows no significant differences between sample and population for some critical characteristics.

The chosen design has the potential for common source bias: A bias that stems from using perceptual measures from the same survey as independent and dependent variables. Unfortunately, there are few ways to unobtrusively, or independently, study professionals' engagement in coproduction (in contrast to, for example, performance). It is very difficult to control for common source bias in such a design (Podsakoff, MacKenzie, Lee, \& Podsakoff, 2003). Within a chosen design, only instrumental variables can solve the problem, but these are hard to obtain (Podsakoff, MacKenzie, $\&$ Podsakoff, 2012). Therefore, we cannot rule out that some of the responses are driven by the chosen survey method.

\section{Measurement of Variables}

To measure the relevant variables, translated and contextualized versions of validated scales were used where possible. To make sure the compound measurement scale worked out in practice, we held pilot interviews. ${ }^{3}$ Below the variables are discussed step by step (see Tables 1 and 2).

The dependent variable is the location manager's selfreported engagement with coproduction. Above we defined engagement as a construct that comprises three dimensions. ${ }^{4}$ We used nonparametric item response scaling for polytomous items (Mokken scale analysis) to assess the scale strength, indicated by Loevinger's $H^{5}$ This measurement model is especially suitable for cumulative scales that aim to tap latent traits of respondents. Cumulative scales do not assume, as "classical" test theory does, that items are perfectly correlated. Rather, item-response scaling models assume that some items are more difficult to respond to-thus being robust when responses are skewed. The responses on self-reported 
Table 2. Composition of the Independent Variables.

\begin{tabular}{|c|c|}
\hline Variable (if applicable: consistency) & Measurement \\
\hline Autonomy & $a=0.83$ \\
\hline "Indicate to what extent you agree or disagree with the following three statements." & \multirow{4}{*}{$\begin{array}{l}\text { 7-point scale (strongly disagree to } \\
\text { strongly agree) }\end{array}$} \\
\hline I. "I am allowed to decide how to go about getting my job done" & \\
\hline 2. "I have some control over the sequencing of my work activities-when I do what" & \\
\hline $\begin{array}{l}\text { 3. "I have some control over what I am supposed to accomplish-what my supervisor } \\
\text { sees as my job objectives" }\end{array}$ & \\
\hline \multicolumn{2}{|l|}{ Autonomy in coproduction } \\
\hline $\begin{array}{l}\text { "Due to collaboration with the client council, I experience ... possibilities to } \\
\text { determine the content and activities of my work." }\end{array}$ & \multirow[t]{2}{*}{ 7-point scale (much less to much more) } \\
\hline $\begin{array}{l}\text { Converted to two dummy variables: (a) respondents indicating "less autonomy"; (b) } \\
\text { respondents indicating "more autonomy" }\end{array}$ & \\
\hline Organizational support & $a=0.84$ \\
\hline $\begin{array}{l}\text { "To what extent does your organization support your collaboration with the client } \\
\text { council?" }\end{array}$ & \multirow[t]{4}{*}{$\begin{array}{l}\text { 7-point scale (strongly disagree to } \\
\text { strongly agree) }\end{array}$} \\
\hline $\begin{array}{l}\text { I. ... through the formulation/adaptation of organizational structures, procedures, and } \\
\text { directives }\end{array}$ & \\
\hline 2. ... through provision of time and resources & \\
\hline 3. ... through stimulating an organizational culture of openness toward coproduction & \\
\hline \multicolumn{2}{|l|}{ General red tape } \\
\hline $\begin{array}{l}\text { "If red tape is defined as 'burdensome administrative rules and procedures that have } \\
\text { negative effects on the organization's effectiveness,' how would you assess the level } \\
\text { of red tape in your organization?" }\end{array}$ & $\begin{array}{l}\text { Grade } 0-10(0=\text { no red tape at all to } \\
10=\text { a very large amount of red tape })\end{array}$ \\
\hline \multicolumn{2}{|l|}{ Coproduction red tape } \\
\hline $\begin{array}{l}\text { "To what extent does collaboration with the client council produce administrative } \\
\text { burden for your work?" }\end{array}$ & $\begin{array}{l}\text { Grade } 0-10(0=\text { no red tape at all to } \\
10=a \text { very large amount of red tape })\end{array}$ \\
\hline
\end{tabular}

engagement with coproduction have, indeed, a cumulative nature and are skewed. For a full discussion on the method, we refer to Van Schuur (2011), and for an application in public management, we refer to Torenvlied, Akkerman, Meier, and O'Toole (2013). An additional advantage of nonparametric item response theory (IRT) for polytomous items is that scale strength can be assessed for two-item constructs.

The first dimension is perceived importance of coproduction in terms of the added value for the organization. We developed two items to tap importance (see Table 1). For two polytomous items, a nonparametric item-response analysis is well-suited for scaling analysis (which cannot be assessed using Cronbach's alpha). Both items, indeed, form a strong scale, as indicated by Loevinger's $H=0.49$. The second dimension, perceived impact, is tapped by three items. Perceived impact pertains to the perceived usefulness and functionality of collaboration with the client council. The three items form a strong scale $(H=0.48)$. The third dimension is personal involvement, referring to the self-reported commitment to the client council in relation to the location manager's intrinsic motivation for collaboration. Three items form a scale of intermediate strength $(H=0.40)$. To assess divergent validity of the three scales, we analyzed correlations between the scales. These correlations are moderate: $.32, .37$, and .39. This indicates that importance, perceived impact, and personal involvement tap different aspects of managers' engagement with coproduction.
Autonomy. The first independent variable, work autonomy, was measured using three standard items taken from Breaugh (1989). We asked respondents for their agreement with the following three statements, on a 7-point scale (varying from strongly disagree to strongly agree): "I am allowed to decide how to go about getting my job done"; "I have some control over the sequencing of my work activities - when I do what"; and "I have some control over what I am supposed to accomplish-what my supervisor sees as my job objectives." The autonomy scale has a strong reliability $(\alpha=.83)$.

Autonomy when working with client council. We specifically measured respondents' perceived autonomy in working with the client council using the following statement: "Due to collaboration with the client council, I experience ... possibilities to determine the content and activities of my work." Responses were measured on a 7-point scale, varying from much less to much more. We recoded this variable into two dummy variables: $(-1)$ "decrease in autonomy" and (+1) "increase in autonomy." Reference category is "no perceived change." Correlation between the measure for job autonomy and the two dummies for coproduction autonomy are -.01 and .07 , respectively, which indicates that general perceptions of job autonomy are unrelated to changes in autonomy due to the coproduction activities. 
Table 3. Summary Statistics for the Variables in the Analysis $(N=278)$.

\begin{tabular}{|c|c|c|c|c|}
\hline & M & $S D$ & Minimum & Maximum \\
\hline \multicolumn{5}{|l|}{ Engagement } \\
\hline Ia. Importance & 12.50 & 1.19 & 8 & 14 \\
\hline Ib. Perceived impact & 13.22 & 2.93 & 2 & 19 \\
\hline Ic. Personal involvement & $11.6 \mid$ & 1.57 & 4 & 14 \\
\hline \multicolumn{5}{|l|}{ Independent variables } \\
\hline 2. Autonomy & 18.15 & 1.77 & 9 & 21 \\
\hline 3a. Less autonomy in coproduction & 0.08 & 0.26 & 0 & I \\
\hline 3b. More autonomy in coproduction & 0.32 & 0.47 & 0 & I \\
\hline 4. Organizational support & 17.54 & 2.10 & 7 & 21 \\
\hline 5. Red tape in coproduction & 4.45 & 2.08 & 0 & 9 \\
\hline 6. Red tape general & 7.24 & 1.60 & 1 & 10 \\
\hline
\end{tabular}

Table 4. Correlation Coefficients.

\begin{tabular}{|c|c|c|c|c|c|c|c|c|}
\hline Variable & Ia & $\mathrm{Ib}$ & Ic & 2 & $3 a$ & $3 b$ & 4 & 5 \\
\hline Ia. Importance & 1.00 & & & & & & & \\
\hline Ib. Perceived impact & .37 & 1.00 & & & & & & \\
\hline Ic. Personal involvement & .34 & .37 & 1.00 & & & & & \\
\hline 2. Autonomy & .06 & .08 & .13 & 1.00 & & & & \\
\hline 3a. Less autonomy in coproduction & -.20 & -.37 & -.21 & -.01 & 1.00 & & & \\
\hline 3b. More autonomy in coproduction & .26 & .35 & .28 & .07 & -.20 & 1.00 & & \\
\hline 4. Organizational support & .35 & .19 & .27 & .08 & -.07 & .11 & 1.00 & \\
\hline 5. Red tape coproduction & -.24 & -.36 & -.30 & -.16 & .27 & -.10 & -.17 & 1.00 \\
\hline 6. Red tape general & -.01 & -.11 & -.03 & -.15 & .05 & .01 & -.07 & .28 \\
\hline
\end{tabular}

Organizational support. To tap the second independent variable, organizational support, we departed from a measure developed by Huang and Feeney (2016) and asked the location manager "To what extent does your organization support your collaboration with the client council?" Answer categories vary on a 7-point Likert-type scale for three forms of support, distinguishing between (a) the formulation/adaptation of organizational structures, procedures, and directives, (b) provision of time and resources, (c) stimulating an organizational culture of openness toward coproduction. An item-response analysis shows that the three items form a strong scale $(\alpha=.84)$.

General red tape. The third independent variable was measured based on Rainey, Pandey, and Bozeman's (1995) general red tape measure: "If red tape is defined as 'burdensome administrative rules and procedures that have negative effects on the organization's effectiveness,' how would you assess the level of red tape in your organization?" Respondents graded between 0 and 10, where " 0 " indicates "no red tape at all" and "10" indicates "a very large amount of red tape."

Coproduction red tape. We also asked about red tape specifically associated with coproduction. We asked location managers "To what extent does collaboration with the client council produce administrative burden for your work?" and used the same 10-point scale. Correlation between "general red tape" and "coproduction red tape" is relatively low, .26indicating that both constructs indeed tap different aspects of red tape in the work environment of the location managers. Tables 3 and 4 provide an overview of the descriptive statistics for the dependent and independent variables in the study and their correlations, respectively.

Control variables. A number of control variables are included in the study to control for potentially confounding variables. Gender was measured in a dummy variable "female." Education was measured as the highest level of education the respondent had obtained, with three categories: (a) lower, secondary, and vocational education; (b) higher professional education; (c) university. Experience of the location manager is measured as the number of years the respondent is working in the current function. Five types of elderly organizations are distinguished in the data: nursing homes $(25 \%)$, elderly homes $(15 \%)$, health care center for elderly $(54 \%)$, integrated facility $(3 \%)$, and other $(3 \%)$. We also control for interaction frequency with the client council, measured by asking the location manager "how frequently do you meet with members of the client council?" (cf. O'Toole \& Meier, 2011; Torenvlied et al., 2013). Responses were recoded in three categories: (a) daily and weekly, (b) monthly, and (c) yearly or never. 
Table 5. Perceived Importance of Client Councils: Results of OLS Regression $(N=278)$.

\begin{tabular}{|c|c|c|c|c|c|c|}
\hline & \multicolumn{3}{|c|}{ Model I } & \multicolumn{3}{|c|}{ Model 2} \\
\hline & $B$ & $(S E)$ & $t$ & $B$ & $(S E)$ & $t$ \\
\hline \multicolumn{7}{|l|}{ Explanatory variables } \\
\hline Autonomy & 0.03 & $(0.04)$ & 0.39 & 0.04 & $(0.04)$ & 0.90 \\
\hline Less autonomy in coproduction ${ }^{\mathrm{a}}$ & -0.53 & $(0.32)$ & -1.68 & -0.62 & $(0.33)$ & -1.89 \\
\hline More autonomy in coproduction ${ }^{\mathrm{a}}$ & 0.47 & $(0.13)$ & $3.61 * * *$ & 0.40 & $(0.14)$ & $2.88 * *$ \\
\hline Organizational support & 0.14 & $(0.03)$ & $5.18^{* * * *}$ & 0.15 & $(0.03)$ & $5.20 * * *$ \\
\hline Support $\times$ Autonomy & 0.05 & $(0.01)$ & $3.4 I^{* *}$ & 0.04 & $(0.02)$ & $2.90 * *$ \\
\hline Red tape in coproduction & -0.10 & $(0.03)$ & $-3.22 * *$ & -0.09 & $(0.03)$ & $-2.62 * *$ \\
\hline Red tape general & 0.06 & $(0.04)$ & 1.50 & 0.06 & $(0.04)$ & 1.52 \\
\hline \multicolumn{7}{|l|}{ Control variables } \\
\hline \multicolumn{7}{|l|}{ Contact ${ }^{\mathrm{b}}$} \\
\hline Monthly & & & & -0.30 & $(0.16)$ & -1.80 \\
\hline Yearly/never & & & & -0.22 & $(0.19)$ & -1.16 \\
\hline Experience & & & & 0.01 & $(0.01)$ & 0.54 \\
\hline Female & & & & 0.04 & $(0.13)$ & 0.30 \\
\hline \multicolumn{7}{|l|}{ Education } \\
\hline High professional ${ }^{c}$ & & & & -0.08 & $(0.24)$ & -0.33 \\
\hline University & & & & -0.06 & $(0.28)$ & -0.21 \\
\hline \multicolumn{7}{|l|}{ Organization type ${ }^{d}$} \\
\hline Health care center & & & & -0.28 & $(0.15)$ & $-1.8 \mid$ \\
\hline Hybrid organization & & & & -0.86 & $(0.38)$ & $-2.24 *$ \\
\hline Other organization & & & & 0.13 & $(0.22)$ & 0.62 \\
\hline Constant & 9.43 & $(0.89)$ & $10.65^{* * *}$ & 9.42 & (1.08) & $8.7 \mid * * *$ \\
\hline$R^{2}$ & .24 & & & .28 & & \\
\hline
\end{tabular}

Note. Robust standard errors clustered in 138 organizations. OLS $=$ ordinary least squares.

${ }^{a}$ No change is reference category.

${ }^{b}$ Daily and weekly contact is reference category.

${ }^{c}$ Vocational education is reference category.

${ }^{\mathrm{d}}$ Nursing home/elderly home are reference categories.

$* p<.05 . * * p<.01$. ***p $<.001$.

\section{Results}

To test the hypotheses, we performed a series of ordinary least squares regression models with robust standards errors. The cases $(N=$ location managers in the analysis) are clustered in 138 health care organizations. The minimum number of councils per organization is one (roughly $20 \%$ of the sample), the average is two, and the maximum is 13 . To control for the statistical dependence between cases within one organization, we computed robust, clustered standard errors nested in the organizations. ${ }^{6}$ Three analyses were performed, each for a specific dimension of location managers' engagement in coproduction: perceived importance, perceived impact, and self-reported involvement.

\section{Perceived Importance}

Table 5 presents the results for the first dimension of location managers' engagement in coproduction: a regression of perceived importance of client councils on the independent variables. Two models are presented. Model 1 presents results for the main independent variables, testing the hypotheses. Model 2 adds control variables to test robustness of effects when introducing potentially confounding variables into the model.

Table 5 shows that work autonomy is not associated with perceived importance. However, respondents who report an increase in autonomy derived from the coproduction process tend to perceive a higher importance of the client councils. Hence, we cannot confirm H1, while H2 finds support in the empirical data. $\mathrm{H} 3 \mathrm{a}$ and $\mathrm{H} 3 \mathrm{~b}$ are both corroborated in the data: perceived organizational support positively and significantly affects perceived importance. Moreover, there is indeed an interaction effect between organizational support and general work autonomy on perceived importance: Under high levels of organizational support, general work autonomy positively affects the perceived importance of client councils. Finally, red tape associated by location managers with coproduction negatively affects perceived importance of the client councils (supporting H4) while perceived general red tape appears to be unrelated with the perceived importance of the client 
Table 6. Perceived Impact of Client Councils: Results of OLS Regression $(N=278)$.

\begin{tabular}{|c|c|c|c|c|c|c|}
\hline & \multicolumn{3}{|c|}{ Model I } & \multicolumn{3}{|c|}{ Model 2} \\
\hline & $B$ & $(S E)$ & $t$ & $B$ & $(S E)$ & $t$ \\
\hline \multicolumn{7}{|l|}{ Explanatory variables } \\
\hline Autonomy & 0.04 & $(0.08)$ & 0.58 & 0.03 & $(0.08)$ & 0.37 \\
\hline Less autonomy in coproduction ${ }^{\mathrm{a}}$ & -2.76 & $(0.7 I)$ & $-3.87 * * *$ & -2.98 & $(0.68)$ & $-4.38 * * *$ \\
\hline More autonomy in coproduction ${ }^{a}$ & 1.65 & $(0.29)$ & $5.68 * * *$ & 1.49 & $(0.29)$ & $5.11 * * *$ \\
\hline Organizational support & 0.10 & $(0.07)$ & $\mathrm{I} .55$ & 0.08 & $(0.07)$ & 1.15 \\
\hline Support $\times$ Autonomy & 0.08 & $(0.03)$ & $2.89 * *$ & 0.07 & $(0.03)$ & $2.4 I^{*}$ \\
\hline Red tape in coproduction & -0.36 & $(0.08)$ & $-4.40 * * *$ & -0.34 & $(0.08)$ & $-4.30 * * *$ \\
\hline Red tape general & -0.03 & $(0.09)$ & -0.35 & -0.05 & (0.09) & -0.58 \\
\hline \multicolumn{7}{|l|}{ Control variables } \\
\hline \multicolumn{7}{|l|}{ Contact ${ }^{\mathrm{b}}$} \\
\hline Monthly & & & & -0.58 & $(0.39)$ & $-|.5|$ \\
\hline Yearly/never & & & & -0.97 & $(0.5 I)$ & -1.90 \\
\hline Experience & & & & -0.02 & $(0.02)$ & -1.21 \\
\hline Female & & & & -0.46 & $(0.33)$ & -1.42 \\
\hline \multicolumn{7}{|l|}{ Education } \\
\hline High professional ${ }^{c}$ & & & & 0.01 & $(0.63)$ & 0.01 \\
\hline University & & & & 0.54 & $(0.77)$ & 0.70 \\
\hline \multicolumn{7}{|l|}{ Organization type ${ }^{d}$} \\
\hline Health care center & & & & -0.67 & $(0.26)$ & $-2.55^{*}$ \\
\hline Hybrid organization & & & & 0.09 & $(0.6 I)$ & -0.15 \\
\hline Other organization & & & & $\mathrm{I} .58$ & $(0.81)$ & 1.95 \\
\hline Constant & 12.03 & $(2.06)$ & $5.83 * * *$ & $|4.5|$ & $(2.20)$ & $6.59 * * * *$ \\
\hline$R^{2}$ & .31 & & & .37 & & \\
\hline
\end{tabular}

Note. Robust standard errors clustered in 138 organizations. OLS = ordinary least squares.

${ }^{a}$ No change is reference category.

bDaily and weekly contact is reference category.

${ }^{c}$ Vocational education is reference category.

${ }^{\mathrm{d}}$ Nursing home/elderly home are reference categories.

$*_{p}<.05$. **p $<.01$. ***p $<.001$.

councils (unconfirming H5). The effects are robust when controlling for individual characteristics of the location manager and characteristics of the client council and parent organization.

\section{Perceived Impact}

Table 6 presents the results for the second dimension of location managers' engagement in coproduction: a regression of perceived impact of the client councils on the independent variables. Table 6 replicates the findings of the previous analysis (supporting $\mathrm{H} 2$ and $\mathrm{H} 4$ ) with the exception of the effect of organizational support, unconfirming H3a. The analysis shows that organizational support does not significantly affect perceived impact of the councils. However, high levels of organizational support and general work autonomy positively affect the perceived importance of client councils, thus supporting H3b. The results remain when controlling for individual characteristics of the location manager and characteristics of the client council and parent organization.

\section{Personal Involvement}

Table 7 presents the results for the third dimension of location managers' engagement in coproduction, a regression of personal involvement in coproduction on the independent variables. Table 7 replicates the results of the first analysis, but for personal involvement, there is no significant interaction effect between organizational support and autonomy. Hence, H2, $\mathrm{H} 3 \mathrm{a}$, and $\mathrm{H} 4$ find support in the empirical data on personal involvement in coproduction, while $\mathrm{H} 1$ and $\mathrm{H} 3 \mathrm{~b}$ cannot be confirmed. Personal involvement in coproduction is positively associated with two individual (control) variables: the existence of interactions with the council and personal experience.

In summary (see Table 8), the hypotheses about the effects of general work autonomy (H1) and general red tape (H5) on location managers' self-reported engagement in coproduction are not confirmed for all three dimensions of engagement. By contrast, autonomy in specific coproduction activities positively (H2) and red tape associated with coproduction negatively (H4) affect all three dimensions of self-reported engagement significantly-as expected. 
Table 7. Self-Reported Personal Involvement in Client Councils: Results of OLS Regression $(N=278)$.

\begin{tabular}{|c|c|c|c|c|c|c|}
\hline & \multicolumn{3}{|c|}{ Model I } & \multicolumn{3}{|c|}{ Model 2} \\
\hline & $B$ & $(S E)$ & $t$ & $B$ & $(S E)$ & $t$ \\
\hline \multicolumn{7}{|l|}{ Explanatory variables } \\
\hline Autonomy & 0.05 & $(0.04)$ & 1.37 & 0.06 & $(0.04)$ & 1.54 \\
\hline Less autonomy in coproduction ${ }^{\mathrm{a}}$ & -0.54 & $(0.38)$ & $-1.44 *$ & -0.70 & $(0.40)$ & -1.77 \\
\hline More autonomy in coproduction ${ }^{a}$ & 0.72 & $(0.15)$ & $4.81 * * *$ & 0.67 & $(0.16)$ & $4.14^{* * *}$ \\
\hline Organizational support & 0.15 & $(0.04)$ & $3.91 * * *$ & 0.13 & $(0.04)$ & $3.22 * *$ \\
\hline Support $\times$ Autonomy & -0.01 & $(0.02)$ & -0.45 & -0.02 & $(0.02)$ & -0.91 \\
\hline Red tape in coproduction & -0.17 & $(0.04)$ & $-3.76 * * *$ & -0.15 & $(0.04)$ & $-3.29 * *$ \\
\hline Red tape general & 0.06 & $(0.05)$ & 1.08 & 0.02 & $(0.05)$ & 0.57 \\
\hline \multicolumn{7}{|l|}{ Control variables } \\
\hline \multicolumn{7}{|l|}{ Contact ${ }^{\mathrm{b}}$} \\
\hline Monthly & & & & -0.37 & $(0.20)$ & -1.86 \\
\hline Yearly/never & & & & -1.19 & $(0.30)$ & $-4.04 * * *$ \\
\hline Experience & & & & 0.03 & $(0.01)$ & $2.45^{*}$ \\
\hline Female & & & & 0.16 & $(0.17)$ & 0.90 \\
\hline \multicolumn{7}{|l|}{ Education } \\
\hline High professional ${ }^{c}$ & & & & -0.05 & $(0.30)$ & -0.15 \\
\hline University & & & & 0.40 & $(0.32)$ & 1.24 \\
\hline \multicolumn{7}{|l|}{ Organization type $^{d}$} \\
\hline Health care center & & & & 0.04 & $(0.17)$ & 0.24 \\
\hline Hybrid organization & & & & -0.14 & $(0.53)$ & -0.26 \\
\hline Other organization & & & & 0.01 & $(0.44)$ & 0.02 \\
\hline Constant & 8.10 & $(1.15)$ & $7.06 * * *$ & 8.33 & $(1.26)$ & $6.62 * * *$ \\
\hline$R^{2}$ & .21 & & & .28 & & \\
\hline
\end{tabular}

Note. Robust standard errors clustered in 138 organizations. OLS = ordinary least squares.

${ }^{a}$ No change is reference category.

b Daily and weekly contact is reference category.

'Vocational education is reference category.

${ }^{\mathrm{d} N u r s i n g}$ home/elderly home are reference categories.

$* p<.05$. **p $<.0$ I. $* * * p<.00$ I.

Table 8. Summary of Research Findings.

\begin{tabular}{|c|c|c|c|}
\hline \multirow[b]{2}{*}{ Hypothesis } & \multicolumn{3}{|c|}{ Dimension of professionals' engagement } \\
\hline & $\begin{array}{l}\text { Perceived } \\
\text { importance }\end{array}$ & $\begin{array}{l}\text { Perceived } \\
\text { impact }\end{array}$ & $\begin{array}{l}\text { Self-reported } \\
\text { personal involvement }\end{array}$ \\
\hline $\begin{array}{l}\text { HI: Professionals' perceived work autonomy positively affects their } \\
\text { engagement in coproduction. }\end{array}$ & Unconfirmed & Unconfirmed & Unconfirmed \\
\hline $\begin{array}{l}\text { H2: Professionals' perceived autonomy in coproduction positively affects } \\
\text { their engagement in coproduction. }\end{array}$ & Confirmed & Confirmed & Confirmed \\
\hline $\begin{array}{l}\text { H3a: Professionals' perception of organizational support for coproduction } \\
\text { positively affects their engagement in coproduction. }\end{array}$ & Confirmed & Unconfirmed & Confirmed \\
\hline $\begin{array}{l}\text { H3b: Professionals' perception of organizational support reinforces the } \\
\text { positive effect of autonomy on engagement in coproduction. }\end{array}$ & Confirmed & Confirmed & Unconfirmed \\
\hline $\begin{array}{l}\text { H4: Professionals perceived levels of red tape associated with } \\
\text { coproduction negatively affects their engagement in coproduction. }\end{array}$ & Confirmed & Confirmed & Confirmed \\
\hline $\begin{array}{l}\text { H5: Professionals perceived levels of general red tape negatively affects } \\
\text { their engagement in coproduction. }\end{array}$ & Unconfirmed & Unconfirmed & Unconfirmed \\
\hline
\end{tabular}

Organizational support for coproduction (H3a) positively affects location managers' perceived importance of coproduction with client councils and their personal involvement with these councils. Organizational support significantly reinforces the positive effect of work autonomy on perceived importance of the client councils (H3b). 


\section{Conclusion and Discussion}

The present study builds upon the recent coproduction literature on the functioning of collaboration between (representatives of) public organizations and coproducers in public service provision. The core assumption in the present study is that coproduction entails a collaborative relationship between public professionals and citizen-users. In the extant literature, insights in public professionals' attitudes remain limited. We studied the engagement of location managers of Dutch organizations for elderly care in their interaction with client councils.

We explained variation in the self-reported engagement of the Dutch location managers from variation in their perceived work autonomy, perceived autonomy related to coproduction, perceived organizational support, level of red tape associated with coproduction, and reported level of general red tape. We included 278 location managers in the study, nested in 138 health organizations for the elderly. The results of our analyses are a first step toward a better understanding of professionals' stance toward coproduction.

Some important findings relate to the concept of engagement in coproduction. Whereas the current literature emphasizes coproducers "credible commitment" (Loeffler \& Hine-Hughes, 2013; Ostrom, 1996), our study shows that the engagement of professionals cannot be taken for granted. Public organizations that want to implement coproduction should take into account that for successful coproduction professionals' engagement can be a prerequisite, as other studies on, for instance, work engagement show (Bakker \& Demerouti, 2008). Our study, moreover, shows that engagement varies among professionals - even in a context where professionals' involvement is mandatory. As collaboration with these client councils is enforced by law, we prevented a selection bias of including professionals who are already in favor of coproduction. Engagement is no unidimensional concept, but rather builds upon different aspects, including professionals' perceptions of the importance and impact of coproduction, and their personal involvement in coproduction.

The descriptive results of our survey provide some interesting insights in managers' engagement with client councils. First, the managers have an overwhelmingly positive stance toward coproducing with clients. Second, $30 \%$ of the studied managers report an increase in autonomy due to the collaboration. Both findings are surprising, as our case concerns a mandatory form of coproduction. That is, managers are forced to coproduce and, as outlined in the theoretical section, especially then we would expect a more negative stance: Professionals have less opportunities to autonomously decide on the work methods, negatively impacting their levels of engagement. Yet, our findings cut directly against these theoretical expectations.

We suggest two explanations, linked to the specific context of the case studied. First, the Dutch health care sector is confronted with huge budget cuts and policy reforms over the past years. Managers interacting with client councils might perceive clients as "allies" in their fight against these cuts/reforms. This brings forward an interesting hypothesis for further research, namely, that professionals utilize coproduction to obtain political leverage, for example, when negotiating with bosses or (other) governmental layers.

Second, the design of this specific coproduction case might reduce the expected loss of autonomy. Although national law obliges collaboration with clients and specifies clients' rights, law does not prescribe in great detail how the interaction should be organized. Managers, therefore, have leeway when it comes to aspects like the frequency of meetings. Furthermore, clients share accountability with managers, potentially reducing feelings of losing managerial control, as stated in the theory section. An additional hypothesis to be explored further, therefore, states that the way in which mandatory coproduction processes are regulated and organized (e.g., only setting a framework or not) impacts on professionals' engagement.

Other findings provide insight in how public organizations are able to affect some of the work environment characteristics that are found to affect professionals' engagement. Coproduction literature suggests the importance of the organization holding a strategic focus on citizen participation and demonstrating credible commitment toward citizens' involvement (see, for instance, Brandsen, Steen, \& Verschuere, 2018). As our empirical study shows the correlation between professionals' engagement in coproduction and perceptions on those work characteristics (i.e., red tape and autonomy) related to the coproduction initiative specifically, we add to this that rather than the characteristics of the organization in general, it is the design of specific coproduction projects itself and the organizational support that is provided for these specific projects that impacts professionals' engagement.

In line with this, our research supports the growing strand in red tape research that addresses red tape not as a onedimensional concept, but rather distinguishes different "types" of red tape and seeks to understand how these might affect organizations differently (see, for example, Pandey et al., 2007). An important conclusion, therefore, is that the difference between the general work environment (work autonomy and red tape) and the specificity of how the coproduction initiative is designed (autonomy in coproduction and red tape associated with coproduction) needs to be acknowledged to avoid false assumptions of the impact of the work environment on individuals' engagement in coproduction.

The difference in correlational strength between the traditional measures of autonomy and red tape and engagement in coproduction compared with the coproduction-related measures of autonomy and red tape could be - at least partiallyinduced by the respondents' assessment of the coproduction context, as we stipulated above. This assessment may have 
induced in respondents a "halo-effect": a systematic bias in responses about coproduction-related measures. Future research should further tease out such halo effects in the coproduction context.

Some practical lessons can be gathered. Organizations, through their structures, procedure and culture, can support professionals in recognizing the dimension of importance and personal involvement in coproduction. Organizational support did not significantly affect the second dimension of engagement: the perceived impact of coproduction. So, organizations can convince their employees of the importance and relevance of coproduction, as well as encourage them to feel personally committed with the collaboration. Yet, organizations can less influence employees' perceptions on the usefulness and functionality of coproduction. Perhaps this is something professionals need to experience themselves in their daily work activities to become convinced of. An avenue for further study is to explore the role of training to stimulate the emergence of norms supporting coproduction.

Furthermore, public organizations are able to affect the explanatory factors related to autonomy and red tape. It is not so much the general work environment (work autonomy and general red tape) but rather their specifications emerging from coproduction itself that affect dimensions of engagement (i.e., autonomy in coproduction and red tape associated with coproduction). Work autonomy only positively significantly affects engagement (in particular the importance of coproduction) when organizational support is perceived to be high.

These findings identify a potential challenge between the need for organizational support and the risk of red tape. Procedures are one of the tools to organize organizational support; yet, organizations should be careful as at the same time the specific design of these procedures can stimulate perceptions of red tape. This balance can be even more complicated as different professionals might perceive the levels of both support and red tape differently. In line with other research, for example, on red tape (e.g., Pandey \& Marlowe, 2015), our study identified the effects of perceived rather than actual support/autonomy/red tape. A valuable suggestion for further research would be to compare how actual work environment characteristics differ among organizations, what actions are undertaken to support professionals, and how this links with different levels of professionals' engagement.

Two important limitations to this study lie in the nature of the data gathered. First, the cross-sectional data makes it possible to observe associations among variables, but not to test causality in the direction of relations. Theoretical claims support the plausibility of the direction of causality we tested, but there is no conclusive empirical evidence that may rule out reversed causality. Indeed, an alternative (reversed causality) argument would be that a lack of coproduction engagement induces perceptions in professionals that collaboration with client councils are administratively burdensome. Future research designs should include more specifically tailored instrumental variables aiming at ruling out such endogeneity problems.

A second potential limitation is linked to the use of surveys as obtrusive instruments for data collection. The present study relies on self-reported data by respondents. The use of self-reported data in this study is valuable, because it focuses on attitudinal and descriptive data on importance, impact, and personal involvement in coproduction. George and Pandey (2017) demonstrate that such variables that are perceptual in nature can hardly be studied without using survey research. In recent years, other studies also emphasize the added value of using self-reported cross-sectional data in similar designs, for example, testing the relation between Public Service Motivation and perceived social impact of employees' work (Stritch \& Christensen, 2014) or officer perceptions of community policing (Glaser \& Denhardt, 2010).

The design, however, bears the risk of common method bias. Inclusion of distinct data sources would be a solution to prevent such a bias. Yet, as such measures are not available at the moment, an important challenge for future coproduction research will be to develop instrumental variables or even an "objective" and independent measurement of engagement. However, when distinct sources cannot be included, this does not automatically imply that the conducted research is prone to common method bias. George and Pandey (2017) and Spector, Rosen, Richardson, Williams, and Johnson (2019) discuss how such a bias can be limited and how the results can be judged. In our design, we paid special attention to the nature of the constructs measured and the semantic wording of the survey questions (cf. Arnulf, Larsen, Martinsen, \& Bong, 2014). Regarding the research results, relevant to note is that the correlation between dimensions of the dependent variable is not high and correlations between independent variables are generally low.

Thus, although the research findings should be put in perspective, given the design limitations, results do contribute to the current coproduction literature. Scholars have only recently started to unravel the impact of coproduction on professionals' work from a theoretical point of view (cf. Alford \& O'Flynn, 2012; Brandsen \& Honingh, 2013). The present study provides new empirical evidence on the correlates of professionals' attitudes toward coproduction with characteristics of their work environment. The dimensions of engagement in coproduction can be further developed and refined to further understanding of professionals' attitudes toward coproduction. The first results are promising, but should be cautiously interpreted, and we very much encourage further research on engagement in coproduction in other contexts. 


\section{Appendix}

Table AI. Comparison of Some Major Characteristics for the Population and Sample: One-Sample $t$ Tests to Check for Nonresponse Bias.

\begin{tabular}{|c|c|c|c|c|}
\hline \multirow[b]{2}{*}{ Characteristic } & \multicolumn{2}{|c|}{ Population $(N=1,970)$} & \multicolumn{2}{|c|}{ Sample $(N=430)$} \\
\hline & Frequency (\%) & M & Frequency (\%) & M \\
\hline \multicolumn{5}{|c|}{ Inclusion in coordinating organization (number of locations) } \\
\hline I location & 6.7 & .07 & 6.7 & .07 \\
\hline 2-5 locations & 18.7 & .19 & 18.4 & .18 \\
\hline 6-10 locations & 28.0 & .28 & 30.2 & .30 \\
\hline$\geq \mathrm{II}$ locations & 46.6 & .47 & 44.7 & .45 \\
\hline Total & 100 & & 100 & \\
\hline \multicolumn{5}{|l|}{ Place of business } \\
\hline Randstad $^{\mathrm{a}}$ & 38.5 & .39 & 37.7 & .38 \\
\hline $\begin{array}{l}\text { Not located in } \\
\text { Randstad }\end{array}$ & 61.5 & .61 & 62.3 & .62 \\
\hline Total & 100.0 & & 100.0 & \\
\hline
\end{tabular}

${ }^{\mathrm{a}}$ The Randstad is the main urban area in the Netherlands.

\section{Acknowledgments}

This article is part of a Research Talent program called "The dynamics of co-production at the street-level," financed by NWO (The Netherlands Organization for Scientific Research). The authors would like to thank Jeffrey Brudney, Taco Brandsen, the participants of the IIAS Study Group on Coproduction of Public Services, and colleagues at the Institute of Public Administration, Leiden University (particularly Petra van den Bekerom, Maarja Beerkens, and Mark Reijnders), for their helpful feedback on an earlier version of this article. They also would like to thank the anonymous reviewers for their helpful suggestions.

\section{Declaration of Conflicting Interests}

The author(s) declared no potential conflicts of interest with respect to the research, authorship, and/or publication of this article.

\section{Funding}

The author(s) disclosed receipt of the following financial support for the research, authorship and/or publication of this article: This paper is part of a Research Talent program called 'The dynamics of co-production at the street-level,' financed by NWO (The Netherlands Organization for Scientific Research).

\section{Notes}

1. Based on the total number of organizations for elderly care mentioned on the websites of the Inspectie voor de Gezondheidszorg (IGZ, Health Care Inspectorate) and ZorgkaartNederland (both consulted January 2014).

2. A response rate of $22 \%$ is comparable to some other studies among staff of nursing homes for elderly; Goergen (2001), for instance, reports 20\%. Evers, Tomic, and Brouwers (2001) report a response rate up to $47 \%$ but used a quite different research strategy: They held face-to-face interviews with respondents from a very limited number of organizations.
3. As we intend to study other cases as well, the pilot interviews were held in the cases of health care, neighborhood watch, councils established as part of the Social Support Act (Wmo), and advisory councils at primary schools.

4. We also empirically checked the validity of the three scales. A principal component analysis over all items reveals the existence of three factors with eigenvalue $>1$. Each factor is strongly correlated with one of the three dimensions; correlations are $.90, .94$, and .96 . We chose to use the separate dimensions because these are better interpretable as dependent variables than are factor scores.

5. As a rule of thumb, we interpret the strength of the $H$ as follows: $H<.30$ is considered a weak scale; $.30<H<.50$ is considered to be an intermediately strong; $H>.50$ is considered to be a strong scale (see Van Schuur, 2011).

6. A multilevel analysis which requires at least two to three observations per higher level unit as a rule of thumb. Therefore, it was not possible to compute an intraclass correlation coefficient which could inform us about the variation of variables to be attributed to the individual versus organizational level.

\section{ORCID iD}

Carola van Eijk (iD https://orcid.org/0000-0003-1141-720X

\section{References}

ActiZ. (2014). Over ActiZ. Retrieved from https://www.actiz.nl/ over-actiz

Alford, J., \& O'Flynn, J. (2012). Rethinking public service delivery: Managing with external providers. Houndmills, UK: Palgrave Macmillan.

Arnulf, J. K., Larsen, K. R., Martinsen, Ø. L., \& Bong, C. H. (2014). Predicting survey responses: How and why semantics shape survey statistics on organizational behaviour. PLOS ONE, 9(9), e106361.

Bakker, A. B., \& Demerouti, E. (2008). Towards a model of work engagement. Career Development International, 13, 209-223.

Bovaird, T. (2007). Beyond engagement and participation: User and community coproduction of public services. Public Administration Review, 67, 846-860.

Bovaird, T., \& Löffler, E. (2012). From engagement to co-production: How users and communities contribute to public services. In V. Pestoff, T. Brandsen, \& B. Verschuere (Eds.), New public governance, the third sector and co-production (pp. 35-60). New York, NY: Routledge.

Bovaird, T., Löffler, E., \& Hine-Hughes, F. (2011). From passive customers to active co-producers: The role of co-production in public services. Retrieved from http://www.mycustomer .com/topic/customer-experience/passive-customers-active-co -producers-role-co-production-public-services/1

Bozeman, B. (2000). Bureaucracy and red tape. Upper Saddle River, NJ: Prentice Hall.

Brandsen, T., \& Honingh, M. (2013). Professionals and shifts in governance. International Journal of Public Administration, 36, 876-883.

Brandsen, T., \& Honingh, M. (2016). Distinguishing different types of coproduction: A conceptual analysis based on the classical definitions. Public Administration Review, 76, 427435. doi:10.1111/puar.12465

Brandsen, T., Pestoff, V., \& Verschuere, B. (2012). Co-production as a maturing concept. In V. Pestoff, T. Brandsen, \& B. 
Verschuere (Eds.), New public governance, the third sector and co-production (pp. 1-9). New York, NY: Routledge.

Brandsen, T., Steen, T., \& Verschuere, B. (2018). How to encourage co-creation and co-production. In T. Brandsen, T. Steen, \& B. Verschuere (Eds.), Co-production and co-creation: Engaging citizens in public services (pp. 299-302). New York, NY: Routledge.

Breaugh, J. A. (1989). The work autonomy scales: Additional validity evidence. Human Relations, 42, 1033-1056.

Brewer, G. A., \& Walker, R. (2010). The impact of red tape on governmental performance: An empirical analysis. Journal of Public Administration Research and Theory, 20, 233-257.

Bucher, R., \& Stelling, J. (1969). Characteristics of professional organizations. Journal of Health and Social Behavior, 1, 3-15.

Calabrò, A. (2012). Co-production: An alternative to the partial privatization processes in Italy and Norway. In V. Pestoff, T. Brandsen, \& B. Verschuere (Eds.), New public governance, the third sector and co-production (pp. 317-336). New York, NY: Routledge.

Davis, R. S., \& Pink-Harper, S. A. (2016). Connecting knowledge of rule-breaking and perceived red tape: How behavioral attribution influences red tape perceptions. Public Performance \& Management Review, 40, 181-200.

Evans, T. (2013). Organisational rules and discretion in adult social work. British Journal of Social Work, 43, 739-758.

Evers, W., Tomic, W., \& Brouwers, A. (2001). Effects of aggressive behavior and perceived self-efficacy on burnout among staff of homes for the elderly. Issues in Mental Health Nursing, $22,439-454$

Ewert, B., \& Evers, A. (2012). Co-production: Contested meanings and challenges for user organizations. In V. Pestoff, T. Brandsen, \& B. Verschuere (Eds.), New public governance, the third sector and co-production (pp. 61-78). New York, NY: Routledge.

Fenwick, T. (2012). Co-production in practice: A sociomaterial analysis. Professions \& Professionalism, 2(2), 1-16.

Fledderus, J. (2015). Building trust through public service co-production. International Journal of Public Sector Management, $28,550-565$.

Florin, D., \& Dixon, J. (2004). Public involvement in health care. British Medical Journal, 328, 159-161.

Flynn, R. (1999). Managerialism, professionalism and quasimarkets. In M. Exworthy \& S. Halford (Eds.), Professionals and the new managerialism in the public sector (pp. 18-36). Buckingham, UK: Open University Press.

Freidson, E. (1994). Professionalism reborn: Theory, prophecy, and policy. Cambridge: Polity Press.

Freidson, E. (2001). Professionalism: The third logic. Cambridge: Polity Press.

George, B., \& Pandey, S. K. (2017). We know the Yin-But where is the Yang? Toward a balanced approach on common source bias in public administration scholarship. Review of Public Personnel Administration, 37, 245-270.

Glaser, M. A., \& Denhardt, J. (2010). Community policing and community building: A case study of officer perceptions. The American Review of Public Administration, 40, 309-325.

Goergen, T. (2001). Stress, conflict, elder abuse and neglect in German nursing homes: A pilot study among professional caregivers. Journal of Elder Abuse \& Neglect, 13(1), 1-26.

Gore, A. (1993). From red tape to results: Creating a government that works better and costs less. Washington, DC: U.S. Government Printing Office.
Huang, W.-L., \& Feeney, M. F. (2016). Citizen participation in local government decision making: The role of manager motivation. Review of Public Personnel Administration, 36, 188209. doi:10.1177/0734371X15576410

Kaufman, H. (1977). Red tape, its origins, uses, and abuses. Washington, DC: Kieser.

Kaufmann, W., \& Tummers, L. G. (2017). The negative effect of red tape on procedural satisfaction. Public Management Review, 19, 1311-1327.

Lees-Marshment, J. (2015). The ministry of public input: Integrating citizen views into political leadership. Hampshire, UK: Palgrave Macmillan.

Lemos, M. C., \& Morehouse, B. J. (2005). The co-production of science and policy in integrated climate assessments. Global Environmental Change, 15, 57-68.

Liao, Y., \& Schachter, H. L. (2018). Exploring the antecedents of municipal managers' attitudes towards citizen participation. Public Management Review, 20, 1287-1308.

Lipsky, M. (2010). Street-level bureaucrats. New York, NY: Russell Sage Foundation. (Original work published 1980)

Loeffler, E., \& Hine-Hughes, F. (2013). Five steps to making the transformation to co-production. In E. Loeffler, G. Power, T. Bovaird, \& F. Hine-Hughes (Eds.), Co-production of health and wellbeing in Scotland (pp. 132-137). Birmingham, UK: Governance International.

Moynihan, D. P. (2003). Normative and instrumental perspectives on public participation: Citizen Summits in Washington, D.C. The American Review of Public Administration, 33, 164-188.

Moynihan, D. P., \& Thomas, J. C. (2013). Citizen, customer, partner: Rethinking the place of the public in public management. Public Administration Review, 73, 786-796.

Osborne, S. P. (2010). Delivering public services: Time for a new theory? Public Management Review, 12, 1-10.

Osborne, S. P., Radnor, Z., \& Nasi, G. (2012). A new theory for public service management? Toward a (public) service-dominant approach. The American Review of Public Administration, 43, 135-158.

Osborne, S. P., \& Strokosch, K. (2013). It takes two to tango? Understanding the co-production of public services by integrating the services management and public administration perspectives. British Journal of Management, 24, 31-47.

Ostrom, E. (1996). Crossing the great divide: Coproduction, synergy, and development. World Development, 24, 1073-1087.

O'Toole, L. J., Jr., \& Meier, K. J. (2011). Public management: Organizations, governance, and performance. Cambridge, UK: Cambridge University Press.

Overheid.nl. (2012). Participation by Clients of Care Institutions Act. Retrieved from https://wetten.overheid.nl/ BWBR0007920/2016-01-01

Pandey, S. K., Coursey, D. H., \& Moynihan, D. P. (2007). Organizational effectiveness and bureaucratic red tape: A multimethod study. Public Performance \& Management Review, 30, 398-425.

Pandey, S. K., \& Marlowe, J. (2015). Assessing survey-based measurement of personnel red tape with anchoring vignettes. Review of Public Personnel Administration, 35, 215-237.

Pandey, S. K., \& Scott, P. G. (2002). Red tape: A review and assessment of concepts and measures. Journal of Public Administration Research and Theory, 12, 553-580.

Pestoff, V. (2012). Co-production and third sector social services in Europe. In V. Pestoff, T. Brandsen, \& B. Verschuere (Eds.), 
New public governance, the third sector and co-production (pp. 13-34). New York, NY: Routledge.

Podsakoff, P. M., MacKenzie, S. B., Lee, J.-Y., \& Podsakoff, N. P. (2003). Common method biases in behavioral research: A critical review of the literature and recommended remedies. Journal of Applied Psychology, 88, 879-903.

Podsakoff, P. M., MacKenzie, S. B., \& Podsakoff, N. P. (2012). Sources of method bias in social science research and recommendations on how to control it. Annual Review of Psychology, 63, 539-569.

Rainey, H. G., Pandey, S., \& Bozeman, B. (1995). Research note: Public and private managers' perceptions of red tape. Public Administration Review, 55, 567-574.

Saks, A. M. (2006). Antecedents and consequences of employee engagement. Journal of Managerial Psychology, 21, 600-619.

Sharp, E. B. (1980). Toward a new understanding of urban services and citizen participation: The coproduction concept. The American Review of Public Administration, 14, 105-118.

Spector, P. E., Rosen, C. C., Richardson, H. A., Williams, L. J., \& Johnson, R. E. (2019). A new perspective on method variance: A measure-centric approach. Journal of Management, 45, 855-880.

Spiegel, H. B. C. (1987). Coproduction in the context of neighborhood development. Journal of Voluntary Action Research, 16(3), 54-61.

Steen, T., \& Tuurnas, S. (2018). The roles of the professional in co-production and co-creation processes. In T. Brandsen, $\mathrm{T}$. Steen, \& B. Verschuere (Eds.), Co-production and co-creation: Engaging citizens in public services (pp. 80-92). Milton Parks, UK: Routledge.

Stritch, J. M., \& Christensen, R. K. (2014). Looking at a job's social impact through PSM-tinted lenses: Probing the motivation-perception relationship. Public Administration, 92, 826-842.

Thomas, J. C. (1999). Bringing the public into public administration: The struggle continues. Public Administration Review, 59, 83-88.

Thomsen, M. K. (2017). Citizen coproduction: The influence of self-efficacy perception and knowledge of how to coproduce. The American Review of Public Administration, 47, 340-353. doi:10.1177/0275074015611744

Tonkens, E., Hoijtink, M., \& Gulikers, H. (2013). Democratizing social work: From New Public Management to democratic professionalism. In M. Noordegraaf \& B. Steijn (Eds.), Professionals under pressure: The reconfiguration of professional work in changing public services (pp. 161-178). Amsterdam, The Netherlands: Amsterdam University Press.

Torenvlied, R., \& Akkerman, A. (2012). Effects of managers' work motivation and networking activity on their reported levels of external red tape. Journal of Public Administration Research and Theory, 22, 445-471.

Torenvlied, R., Akkerman, A., Meier, K. J., \& O'Toole, L. J., Jr. (2013). The multiple dimensions of managerial networking. The American Review of Public Administration, 43, 251-272.

Tummers, L., \& Bekkers, V. (2014). Policy implementation, streetlevel bureaucracy, and the importance of discretion. Public Management Review, 16, 527-547.

Van de Bovenkamp, H. M. (2010). The limits of patient power: Examining active citizenship in Dutch health care. Rotterdam, The Netherlands: Optima Grafische Communicatie.

Van den Bekerom, P., Torenvlied, R., \& Akkerman, A. (2017). Constrained by red tape: How managerial networking moderates the effects of red tape on public service performance. The American Review of Public Administration, 47, 300-322. doi:10.1177/0275074015623856
Van Dijck, C., \& Steen, T. (2017). Collaborating for innovation: A systematic review of red tape as a barrier for coproducing public services. In Conference Proceedings of IIAS Study Group on Coproduction of Public Services (pp. 150-172). Washington, DC.

Van Eijk, C. J. A. (2018). Helping Dutch neighborhood watch schemes to survive the rainy season: Studying mutual perceptions on citizens' and professionals' engagement in the co-production of communitysafety. VOLUNTAS:International Journal of Voluntary and Nonprofit Organizations, 29, 222-236.

Van Eijk, C. J. A., \& Steen, T. P. S. (2014). Why people co-produce: Analysing citizens' perceptions on co-planning engagement in health care services. Public Management Review, 16, 358-382.

Van Eijk, C. J. A., \& Steen, T. P. S. (2016). Why engage in co-production of public services? Mixing theory and empirical evidence. International Review of Administrative Sciences, 82, 28-46.

Van Schuur, W. H. (2011). Ordinal item response theory: Mokken scale analysis. Thousand Oaks, CA: SAGE.

Verschuere, B., Brandsen, T., \& Pestoff, V. (2012). Co-production: State of the art in research and the future agenda. VOLUNTAS: International Journal of Voluntary and Nonprofit Organizations, 23, 1083-1101.

Voorberg, W. H., Bekkers, V. J. J. M., \& Tummers, L. G. (2015). A systematic review of co-creation and co-production: Embarking on the social innovation journey. Public Management Review, 17, 1333-1357.

Voorberg, W., Tummers, L., Bekkers, V., Torfing, J., Tonurist, P., Kattel, R., . . . Osborne, S. (2015). Co-creation and citizen involvement in social innovation: A comparative case study across 7 EU-countries. LIPSE.

Walter, V. (1987). Volunteers and bureaucrats: Clarifying roles and creating meaning. Nonprofit and Voluntary Sector Quarterly, 16(3), 22-32.

Yang, K., \& Callahan, K. (2007). Citizen involvement efforts and bureaucratic responsiveness: Participatory values, stakeholder pressures, and administrative practicality. Public Administration Review, 67, 249-264.

\section{Author Biographies}

Carola van Eijk is assistant professor at the Institute of Public Administration, Leiden University, the Netherlands. Her ongoing research includes aspects of why citizens and public professionals are willing to engage in co-production, how these individuals collaborate and interact, and the challenges public professionals have to cope with.

Trui Steen is professor of Public Governance and Coproduction of Public Services in the Public Governance Institute at KU Leuven, Belgium. Her research includes topics such as professionalism, public service motivation, professional-citizen co-production of public services, central-local government relations and collaborative innovation in the public sector. She chairs the IIAS Study Group on Co-production of Public Services.

René Torenvlied is professor of Public Management in the Department of Public Administration, Twente University, the Netherlands. He studies how management, collaboration, and regulation in technologically advanced societies promote the public interest. Empirical domains of interest are: safety and security, education, health, urban studies, industrial relations, and citizen co-production. 